\title{
JOURNAL OF WORLD LANGUAGES
}

\section{EDITOR-IN-CHIEF}

Wei He

Beijing Foreign Studies University, China

\section{CO-EDITORS}

\section{Jonathan Webster}

City University of Hong Kong,

China

\section{Guowen Huang}

South China Agricultural University, China

Ángel Garralda Ortega

Lingnan University,

China

\section{ASSOCIATE EDITORS}

Khawlah Ahmed

American University of Sharjah, United Arab Emirates
Alice Caffarel-Cayron

University of Sydney,

Australia

Lise Fontaine

Cardiff University, United Kingdom

Adolfo Martín García

Universidad de San Andrés, Argentina

\section{HONORARY BOARD}

Adam Jaworski

The University of Hong Kong, China

Yuming Li

Beijing Language and Culture University,

China

\section{DE GRUYTER MOUTON}


Journal of World Languages is an international, peer-reviewed multidisciplinary journal that explores the roles, functions and structures of languages in the world. Special attention is given to studies of languages in the fields of ecolinguistics (including the Haugenian Tradition and the Hallidayan Tradition), systemic functional linguistics, critical/positive/multimodal/ecological discourse analysis, sociolinguistics, cognitive linguistics, corpus linguistics, pragmatics, linguistic typology, linguistic anthropology and philosophy of language.

ABSTRACTED/INDEXED IN Baidu Scholar · BLL Bibliographie Linguistischer Literatur . CNKI Scholar (China National Knowledge Infrastructure) · CNPIEC: cnpLINKer · Dimensions · ERIH PLUS (European Reference Index for the Humanities and Social Sciences) · Google Scholar . IBR (International Bibliography of Reviews of Scholarly Literature in the Humanities and Social Sciences) - IBZ (International Bibliography of Periodical Literature in the Humanities and Social Sciences) · J-Gate $\cdot$ JournalGuide $\cdot$ JournalTOCs $\cdot$ KESLI-NDSL (Korean National Discovery for Science Leaders) · Microsoft Academic · MyScienceWork · Naver Academic · Naviga (Softweco) Norwegian Register for Scientific Journals, Series and Publishers · Primo Central (ExLibris) - Publons · QOAM (Quality Open Access Market) · ReadCube · Semantic Scholar · Sherpa/RoMEO · Summon (ProQuest) · TDNet · Ulrich's Periodicals Directory/ulrichsweb · WanFang Data · WorldCat (OCLC) . Yewno Discover

The publisher, together with the authors and editors, has taken great pains to ensure that all information presented in this work reflects the standard of knowledge at the time of publication. Despite careful manuscript preparation and proof correction, errors can nevertheless occur. Authors, editors and publisher disclaim all responsibility for any errors or omissions or liability for the results obtained from use of the information, or parts thereof, contained in this work.

ISSN 2169-8252 · e-ISSN 2169-8260

All information regarding notes for contributors, subscriptions, back volumes and orders is available online at https://www.degruyter.com/JWL

RESPONSIBLE EDITOR Wei He, National Research Centre for Foreign Language Education, Beijing Foreign Studies University, No. 19 North Xisanhuan Road, Beijing, 100089, China. E-mail: francesweihe@bfsu.edu.cn

PUBLISHER Walter de Gruyter GmbH, Berlin/Boston, Genthiner Straße 13, 10785 Berlin, Germany

JOURNAL COORDINATOR Alexander Görlt, De Gruyter, Genthiner Straße 13, 10785 Berlin, Germany. Tel.: +49 (0)30 260 05-234, E-mail: alexander.goerlt@ degruyter.com

RESPONSIBLE FOR ADVERTISEMENTS Markus Kügel, De Gruyter, Rosenheimer Str. 143, 81671 München, Germany. Tel.: +49 8976 902-424, E-mail: anzeigen@ degruyter.com

Published by Walter de Gruyter GmbH and Foreign Language Teaching and Research Publishing Co., Ltd. on behalf of (C) 2021 Beijing Foreign Studies University, China

TYPESETTING TNQ Technologies, Chennai, India 


\section{Contents}

\section{Research Articles}

Stephen J. Cowley

Ecolinguistics reunited: Rewilding the territory — 405

Ming Cheng and Wei He

News reports about the Sino-US trade war: An ecolinguistic approach -428

Wenjuan Zhou

Ecolinguistics: A half-century overview — 461

Lei Lei

Exploring ecological identity from the perspective of systemic functional linguistics -487

Delu Zhang and Ruiyun $\mathrm{Hu}$

The appliability of systemic functional linguistics and its role in discipline integration -515

\section{Yumin Chen}

Exploring modality in multimodal macrogenre: A social semiotic analysis of EFL pedagogic materials in China -536

Man Guo and Qingshun He

A corpus-based study of the ADJ-looking adjectivization in English -551

\section{Book Review}

Minchen Wang

Zhihui Fang. 2021. Demystifying academic writing: Genres, moves, skills, and strategies -575 